\title{
BMJ Open Prevalence of health services usage and associated factors in the Amazon region of Brazil: a population-based cross- sectional study
}

Maria Elizete A Araujo, ${ }^{1,2}$ Marcus T Silva, ${ }^{3,4}$ Tais F Galvao, ${ }^{5}$ Mauricio G Pereira ${ }^{6}$

To cite: Araujo MEA, Silva MT, Galvao TF, et al. Prevalence of health services usage and associated factors in the Amazon region of Brazil: a population-based crosssectional study. BMJ Open 2017;7:e017966. doi:10.1136/ bmjopen-2017-017966

- Prepublication history for this paper is available online. To view these files, please visit the journal online (http://dx.doi. org/10.1136/bmjopen-2017017966).

Received 28 May 2017

Revised 16 October 2017

Accepted 25 October 2017

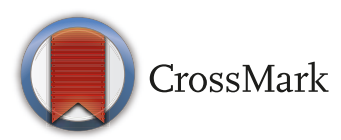

${ }^{1}$ Post-Graduate Program Health Sciences, University of Brasilia, Brasilia, Federal District, Brazil ${ }^{2}$ Getulio Vargas University Hospital, Federal University of Amazonas, Manaus, Amazonas, Brazil

${ }^{3}$ Faculty of Medicine, Federal University of Amazonas, Manaus, Amazonas, Brazil ${ }^{4}$ Post-Graduate Program of Pharmaceutical Sciences, University of Sorocaba,

Sorocaba, Sao Paulo, Brazil

${ }^{5}$ Faculty of Pharmaceutical Sciences, State University of Campinas, Campinas, Sao Paulo, Brazil

${ }^{6}$ Faculty of Medicine, University of Brasilia, Brasilia, Federal District, Brazil

Correspondence to Dr Maria Elizete A Araujo; elizetemanaus@gmail.com

\section{ABSTRACT}

Objectives To estimate the prevalence of healthcare use and associated factors in the Manaus metropolitan region and to describe the reasons for lack of access.

Design Cross-sectional population-based study. Setting A survey conducted between May and August of 2015 in eight cities from Manaus metropolitan region, Amazonas, Brazil.

Participants 4001 adults $\geq 18$ years of age.

Primary outcomes measures Physician visits, dentist visits and hospitalisations in the last 12 months were the primary outcomes. Associated factors were investigated through the calculation of prevalence ratio (PR) obtained by hierarchical Poisson regression modelling.

Results 4001 adults were included in the study, 53\% of whom were women. The self-reported prevalence of medical visits was $77 \%(95 \% \mathrm{Cl} 75 \%$ to $77 \%)$; dentist visits, 36\% (95\% Cl 34\% to 37\%) and hospital admission, $7 \%$ (95\% Cl $6 \%$ to $7 \%)$. Physician visits were higher in women $\mathrm{PR}=1.18$ (95\% $\mathrm{Cl} 1.14$ to 1.23$)$, the elderly $\mathrm{PR}=1.18(95 \% \mathrm{Cl} 1.10$ to 1.26$)$ and people with health insurance $\mathrm{PR}=1.14(95 \% \mathrm{Cl} 1.10$ to 1.19$)$. Dentist visits declined with older age $\mathrm{PR}=0.38(95 \% \mathrm{Cl} 0.30$ to 0.49$)$, lower education level $\mathrm{PR}=0.62(95 \% \mathrm{Cl} 0.51$ to 0.74$)$ and lower economic class PR=0.65 (95\% $\mathrm{Cl} 0.57$ to 0.75$)$. Hospitalisations were found to be twice as frequent for women than for men and three times as frequent among those who reported very poor health status. Among the individuals who did not receive medical attention in the previous 2 weeks, $58 \%$ reported lack of facilities or appointment unavailable and $14 \%$ reported lack of doctors.

Conclusion While more than half visited the doctor in the last year, a lower proportion of people with socioeconomic inequities visited the dentist. Organisational and service policies are needed to increase equity in health services in the region.

\section{BACKGROUND}

The use of health services is the result of the interaction of individuals in need of health service with the health services infrastructure, including technology, supplies and professional services. ${ }^{12}$ In the last several decades, special attention has been directed
Strengths and limitations of this study

- This is the first study to examine the prevalence, pattern and socioeconomic of physician and dentist visits and hospitalisations among adults in the Manaus metropolitan region, using data from representative cross-sectional survey.

- We recruited the participants using probabilistic sampling in three stages, stratified by sex and age quotas based on official estimates.

- This study contributes to a better knowledge of the epidemiological factors associated with use healthcare services in Amazon region.

- Common limitations of cross-sectional designs are present: the outcomes were measured at a single point in time, making it impossible to establish causality.

to the study of the usage and access to health services in Brazil and in the rest of the world, with the aim of identifying inequality and proposing measures to reduce it. ${ }^{9}$

Population-based surveys are important tools in evaluating the health of a population. When analysing the relationship between health and medical services, such surveys also enable the identification of social gaps in healthcare access and the distribution of risk factors in the population. Information extracted from these studies support the planning, organisation and monitoring of health actions. ${ }^{45}$

In 2013, a nationwide Brazilian survey assessed the health service usage in the previous year by examining physician visits $(61 \%-75 \%)$, dentist visits $(34 \%-52 \%)$ and hospitalisations $(5.7 \%-7.5 \%)$ within various regions through self-reported data. ${ }^{6}$ The regional characteristics of the area influences the availability and usage of health services. A systematic review of population-based studies observed an increase in medical and dental consultations from 1998 to 2013 in Brazil countrywide. ${ }^{7}$ In the northern-and 
less developed region-the usage of such health services reduced in this period. Discrepancies in the health services usage in this region may affect the population's well-being and should be investigated.

The aim of this study is to estimate the prevalence of healthcare use and its associated factors in the Manaus metropolitan region, and to describe the reasons for lack of access.

\section{METHODS}

\section{Study design}

This is a cross-sectional population-based study. Primary outcomes were physician visits, dentist visits and hospitalisations in the last 12 months. The present analysis is part of a larger study which aimed to study use of health services and inputs in the region held from May to August $2015 .{ }^{8}$

\section{Setting}

Amazonas has the greatest land area and yet the lowest population density in Brazil; over $60 \%$ of its population is concentrated in the Manaus metropolitan region, formed by the capital, Manaus, and seven other neighbouring cities. ${ }^{9}$ The intermunicipal transportation system relies chiefly on waterways, and there are great distances between the outlying cities and the capital, which is the largest provider of healthcare services. The area ranks 19th out of 20 in the human development index of Brazilian metropolitan regions. ${ }^{10}$ Such characteristics influence the availability and access to health assistance in the region and therefore the use of health service.

\section{Participants}

Adults $\geq 18$ years old were eligible for the study. We recruited the participants using probabilistic sampling in three stages, stratified by sex and age quotas based on official estimates. ${ }^{11}$ In the first stage, we randomly selected 400 primary and 20 secondary census tracts from among the 2647 urban census tracts in the metropolitan region. ${ }^{12}$ The second stage was based on a systematic procedure to include 10 dwellings in each of the selected tracts. We drew a number between 1 and 20 to determine the first residence to visit; after this visit, every 20th house was visited until we reached 10 interviews per census tract. In cases of empty houses or refusals, the house immediately to the right was approached, and if this house was unavailable, the same process was performed to the left. In the third stage, all the local residents $\geq 18$ years old present in the domicile were registered, and one was drawn to be interviewed using predefined age and sex quotas according to the official census.

\section{Variables}

We analysed three dependent variables: (1) visit to physician in last year, measured by the question 'When did you last see a doctor?' with the options 'in the last 12 months', 'from 2 to less than 1 year', 'from 2 to less than 3 years',
'3 years or more', 'never went to the doctor'; (2) visit to dentist in the last year, measured by the question 'When did you last see a dentist?' with the options 'in the last 12 months', 'from 2 to less than 1 year', 'from 2 to less than 3 years', ' 3 years or more', 'never went to the dentist' and (3) admission to hospital in the last year, measured by the question 'in the last 12 months, how many times have you been admitted to a hospital for 24 hours or more?', respondents informed the number of times. All dependent variables were dichotomised to yes (visit in the last year) or no (no visit in the last year).

Independent variables included sex (male, female), age (in years and categorised to 18-24, 25-34, 35-44, 45-59, $\geq 60$ ), marital status (single, married, separated, widowed), self-reported skin colour (white, yellow, black, brown, indigenous), education (higher education, high school, middle school, elementary school or less), occupation (formal job, informal job, retired, student, housewife and unemployed) and economic classification according to the Brazilian economic classification criteria. ${ }^{13}$ This economic classification considers the amount of household appliances and the educational attainment of the family head to classify into A, B, C, D and E, where A signifies wealthier and $\mathrm{E}$, the poorest. The household monthly income in Brazilian real can be estimated from each stratum, which was converted to US $\$$ based on the currency of the Central Bank of Brazil on 1 July 2015: US $\$ 1=\mathrm{R} \$ 3.1185$.

We also assessed private health insurance (yes, no), health status (very good, good, fair, bad, very bad), place of attendance (capital, countryside) and if the respondent has health reference, that is, use the same healthcare or professional for attendance (yes or no).

Secondary outcomes, assessed descriptively were: service or professional sought to aid personal health in the last 15 days, success on the first trial, reason for the lack of assistance, how many repeated attempts, main health procedure received and reason why health service was not sought out in the fortnight.

\section{Data sources and measurement}

Fourteen trained and experienced interviewers collected data using a mobile electronic device (Samsung Galaxy Tab3 SM-T110). The records of the interviews were transmitted via the internet and stored using the software SurveyToGo (Dooblo, Israel). Adequate comprehension of the instrument was ensured by a pretest with 150 interviews.

To minimise the risk of information bias, a phone audit was held with $20 \%$ of the participants. To assure the reliability of the data, the place of the interview was georeferenced, and part of the interview was recorded.

\section{Study size}

The sample size was calculated based on an estimate of $50 \%$ of the prevalence of health services usage, considering a CI of $95 \%$, accuracy of $2 \%$ and a design effect value of $1.5{ }^{14}$ From the official estimate of 2106322 
Table 1 Characteristics of population and prevalence of physician visit, dentist visit and hospitalisation in the previous year

Prevalence $(\%)^{*}$

\begin{tabular}{|c|c|c|c|c|c|c|c|}
\hline \multirow[b]{2}{*}{ Variable } & \multirow[b]{2}{*}{ n (\%) } & \\
\hline & & Physician & $P$ value & Dentist & $P$ value & Hospital & $P$ value \\
\hline Overall & $4001(100.0)$ & 76.5 & & 35.6 & & 6.8 & \\
\hline Sex & & & $<0.001$ & & $<0.001$ & & $<0.001$ \\
\hline Male & $1888(47.2)$ & 69.8 & & 32.7 & & 3.9 & \\
\hline Female & $2113(52.8)$ & 82.6 & & 38.7 & & 9.3 & \\
\hline Age group & & & $<0.001$ & & $<0.001$ & & 0.672 \\
\hline $18-24$ & $838(20.8)$ & 73.0 & & 44.3 & & 7.9 & \\
\hline $25-34$ & 1152 (28.8) & 74.3 & & 40.3 & & 6.6 & \\
\hline $35-44$ & $843(21.1)$ & 78.5 & & 37.9 & & 6.1 & \\
\hline $45-59$ & $772(19.3)$ & 77.4 & & 27.8 & & 6.5 & \\
\hline$\geq 60$ & $396(9.9)$ & 85.1 & & 16.4 & & 7.1 & \\
\hline Marital status & & & $<0.001$ & & $<0.001$ & & 0.375 \\
\hline Single & $2173(54.3)$ & 74.5 & & 37.1 & & 6.5 & \\
\hline Married & 1409 (35.2) & 80.3 & & 37.8 & & 6.8 & \\
\hline Separated/divorced & $260(6.5)$ & 70.3 & & 25.3 & & 7.3 & \\
\hline Widower/widow & $159(4.0)$ & 81.9 & & 18.9 & & 10.0 & \\
\hline Race/colour & & & 0.612 & & 0.230 & & 0.605 \\
\hline White/yellow & 774 (19.3) & 75.8 & & 37.7 & & 7.2 & \\
\hline Black/brown/indigenous & $3227(80.6)$ & 76.7 & & 35.4 & & 6.7 & \\
\hline Education & & & 0.021 & & $<0.001$ & & 0.774 \\
\hline Higher education or above & $158(4.0)$ & 78.6 & & 53.3 & & 8.1 & \\
\hline High school & 1903 (47.6) & 75.0 & & 42.2 & & 6.4 & \\
\hline Middle school & $649(16.2)$ & 75.0 & & 34.7 & & 6.7 & \\
\hline Elementary school or less & $1291(32.2)$ & 79.4 & & 24.4 & & 7.1 & \\
\hline Economic classification $†$ & & & 0.439 & & $<0.001$ & & 0.512 \\
\hline$A-B$ & $629(15.7)$ & 78.7 & & 53.0 & & & 6.8 \\
\hline $\mathrm{C}$ & $2285(57.1)$ & 75.1 & & 35.0 & & & 6.4 \\
\hline D-E & $1087(27.1)$ & 78.3 & & 27.3 & & & 7.5 \\
\hline Occupation & & & $<0.001$ & & $<0.001$ & & $<0.001$ \\
\hline Formal job & $761(19.6)$ & 79.7 & & 46.3 & & 7.6 & \\
\hline Informal job & $1149(28.7)$ & 68.8 & & 32.6 & & 4.1 & \\
\hline Retired & $315(7.9)$ & 85.0 & & 16.7 & & 7.3 & \\
\hline Student/housewife & 1199 (29.9) & 78.0 & & 38.0 & & 9.3 & \\
\hline Unemployed & $577(14.4)$ & 80.1 & & 34.3 & & 5.5 & \\
\hline Private health insurance & & & $<0.001$ & & $<0.001$ & & 0.512 \\
\hline Yes & $523(13.0)$ & 87.6 & & 50.8 & & 7.5 & \\
\hline No & $3478(87.0)$ & 74.9 & & 33.6 & & 6.7 & \\
\hline Health status & & & $<0.001$ & & $<0.001$ & & $<0.001$ \\
\hline Very good & 471 (11.9) & 53.8 & & 29.7 & & 4.6 & \\
\hline Good & $2175(54.3)$ & 77.0 & & 39.7 & & 5.5 & \\
\hline Fair & $1108(27.7)$ & 83.9 & & 32.4 & & 8.7 & \\
\hline Bad & $193(4.8)$ & 85.9 & & 31.9 & & 10.9 & \\
\hline Very bad & $54(1.3)$ & 75.9 & & 20.3 & & 22.2 & \\
\hline City & & & 0.141 & & 0.072 & & 0.002 \\
\hline Capital & 3479 (86.8) & 76.9 & & 36.4 & & 7.3 & \\
\hline Countryside & $522(13.1)$ & 74.0 & & 32.3 & & 3.7 & \\
\hline Health reference & & & $<0.001$ & & $<0.001$ & & $<0.001$ \\
\hline Yesł & $2434(60.8)$ & 80.1 & & 38.2 & & 84.9 & \\
\hline No & 1567 (39.2) & 71.1 & & 32.2 & & 41.8 & \\
\hline
\end{tabular}

*Descriptive statistics using simple frequency and Pearson $\chi^{2}$ test.

†Average household income in 2015: A-B, US\$6500-US\$1419; C, US\$463-US\$772; D-E, US\$205.

‡People who use the same healthcare or professional for attendance. 
residents $\geq 18$ years old in the region in 2015 , ${ }^{11}$ we reached a sample of 3598 individuals. To compensate for inevitable attrition, we added $10 \%$ to this number.

\section{Statistical methods}

Initially, the descriptive statistics of the variables measured in the study were obtained by calculating their frequency and stratification by physician visits, dentist visits and hospital admission. In this step, any differences among the proportions were identified by a Pearson $\chi^{2}$ calculation. Subsequently, bivariate analyses were performed between all independent and dependent variables to calculate the prevalence ratio (PR).

To identify the factors associated with the use of these services, PRs were adjusted in a hierarchical mode ${ }^{15}$ and calculated together with a 95\% CI using Poisson regression with robust variance and $\mathrm{P}$ value adjusted using the Wald test. The calculation of PRs by this method provides more accurate measures, avoiding overestimations. ${ }^{16} 17$

A hierarchical model consisting of three blocks was constructed of most distal determinant for outcome proximate: (1) demographic variables (sex, age, race, marital status); (2) socioeconomic variables (education, economic classification, occupation) and (3) health variables (private health insurance, health status, place of attendance, multiple attempts to seek same health service). From the first block, the variables for the next step were maintained if they presented a significance with $\mathrm{P} \leq 0.05$. The multicollinearity between the independent variables was investigated through variance inflation factors. ${ }^{18}$

Data analysis was carried out in Stata V.14.2 (Stata). In all the calculations, the complex sampling design was weighted by incorporation of sample weights (svy command).

\section{Ethical considerations}

All the individuals who agreed to participate signed a free and informed consent term.

\section{RESULTS}

\section{Participants}

A total of 4001 adults were interviewed, with a $24 \%$ rate of refusal. The sample consisted of 53\% women (table 1). Most reported brown skin colour (72.2\%), and 1\% identified as indigenous. Half the subjects were between 18 and 34 years old, were single and had completed high school. The predominant economic class was lower middle (C class, 57\%; monthly income US $\$ 463-\mathrm{US} \$ 772$ ), about one-third were in informal work, and most reported being in good health $(54 \%)$.

\section{Physician visits in the last year}

The prevalence of physician visits in the last year was $77 \%$ (95\% CI $75 \%$ to $77 \%$ ). Women, the elderly, widows/ widowers, retirees, individuals who do not work and individuals who report poor health status accounted for the majority (over $80 \%$ ) of respondents who had a physician visit in the last 12 months (table 1 ).

Table 2 shows the adjusted analyses. The variables that remained positively associated with statistical significance after adjusting for the demographic block were female sex $(\mathrm{PR}=1.18,95 \%$ CI 1.14 to 1.23$)$ and older age $(\mathrm{PR}=1.18$, $95 \%$ CI 1.10 to 1.26$)$. In the socioeconomic block, education levels did not influence the number of consultations. Lower PRs were observed in social class $\mathrm{C}(\mathrm{PR}=0.94$, $95 \%$ CI 0.89 to 0.98 ) and among individuals with informal job ( $\mathrm{PR}=0.84,95 \%$ CI 0.80 to 0.89 ), students and housewives $(\mathrm{PR}=0.89,95 \% \mathrm{CI} 0.84$ to 0.94$),(\mathrm{P}<0.001)$. Access to health insurance ( $\mathrm{PR}=1.14,95 \% \mathrm{CI} 1.10$ to 1.19$)$ and lower perceptions in the health status were factors associated with higher prevalence of visits to physician in the last block.

\section{Dentist visits in the last year}

The interviewees reported $36 \%$ (95\% CI 34\% to 37\%) of dentist consultations in the last year. The lower the educational level ( $\mathrm{PR}=0.62$, 95\% CI 0.51 to 0.74$)$, income level $(\mathrm{PR}=0.65,95 \% \mathrm{CI} 0.57$ to 0.75$)$, higher age $(\mathrm{PR}=0.38$, $95 \%$ CI 0.30 to 0.49 ), the lower the rate of dental consultation. Factors associated to higher dentist consultation rate included: women, married individuals, private health insurance coverage, formal job, people with good, regular and bad health status and people who use the same health service (table 2).

\section{Hospital admissions in the last year}

The frequency of hospitalisation in the last year was $7 \%$ $(95 \%$ CI $6 \%$ to $8 \%)$. Women, poorer individuals, individuals reporting very bad health status, students and housewives, people who use the same health service and those who live in Manaus were hospitalised more often.

After adjustment, women were two times more likely to be hospitalised than men. Individuals reporting bad health status were three times more likely to be hospitalised than those reporting good health. People who seek for the same health service also were more admitted to the hospital ( $\mathrm{PR}=1.75$, CI 95\% 1.31 to 2.38). People with informal job ( $\mathrm{PR}=0.52,95 \% \mathrm{CI} 0.36$ to 0.77 ) or unemployed ( $\mathrm{PR}=0.63,95 \%$ CI 0.41 to 0.97 ), who live in the countryside job ( $\mathrm{PR}=0.52,95 \%$ CI 0.37 to 0.90$)$ were significantly less hospitalised in the last year.

\section{Reasons behind the demand for health services and lack of access in the last 2 weeks}

Table 3 presents the reasons behind the demand for health services and lack of access to it in the previous 15 days; $48 \%$ of respondents reported usually seeking tertiary service when in need of medical assistance, and $76 \%$ had their last consultation with a general practitioner. One-fifth sought care in the previous 15 days and cited disease as the reason. Eighty-four per cent of people who sought a health service in the fortnight succeeded to use a health service on the first attempt. Among the individuals who did not receive medical attention in the previous 2 weeks, 
Table 2 Adjusted prevalence ratio (PR) and 95\% Cls for physician visit, dentist visit and hospitalisation in the previous year based on hierarchical Poisson

\begin{tabular}{|c|c|c|c|c|c|c|}
\hline \multirow[b]{2}{*}{ Variable } & \multicolumn{2}{|l|}{ Physician } & \multicolumn{2}{|l|}{ Dentist } & \multicolumn{2}{|l|}{ Hospitalisation } \\
\hline & PR $(95 \%$ Cl) & P value* & PR $(95 \% \mathrm{Cl})$ & P value* & PR $(95 \% \mathrm{Cl})$ & P value* \\
\hline \multicolumn{7}{|l|}{ Demographic block $†$} \\
\hline Sex & & $<0.001$ & & $<0.001$ & & $<0.001$ \\
\hline Male & 1.00 & & 1.00 & & 1.00 & \\
\hline Female & 1.18 (1.14 to 1.23$)$ & & 1.18 (1.08 to 1.28$)$ & & 2.32 (1.79 to 3.01$)$ & \\
\hline Age group (years) & & $<0.001$ & & $<0.001$ & & 0.520 \\
\hline $18-24$ & 1.00 & & 1.00 & & 1.00 & \\
\hline $25-34$ & 1.01 (0.96 to 1.07$)$ & & 0.89 (0.80 to 0.99$)$ & & 0.82 (0.59 to 1.12 ) & \\
\hline $35-44$ & 1.06 (1.01 to 1.13$)$ & & 0.82 (0.73 to 0.93$)$ & & 0.75 (0.52 to 1.07$)$ & \\
\hline $45-59$ & 1.06 (1.00 to 1.12$)$ & & 0.61 (0.53 to 0.70$)$ & & 0.78 (0.54 to 1.13$)$ & \\
\hline$\geq 60$ & 1.18 (1.10 to 1.26$)$ & & 0.38 (0.30 to 0.49$)$ & & 0.74 (0.46 to 1.22$)$ & \\
\hline Marital status & & 0.001 & & 0.003 & & 0.459 \\
\hline Single & 1.00 & & 1.00 & & 1.00 & \\
\hline Married & 1.05 (1.01 to 1.09$)$ & & 1.15 (1.05 to 1.26$)$ & & 1.11 (0.85 to 1.44$)$ & \\
\hline Separated/divorced & 0.92 (0.84 to 0.99$)$ & & 0.90 (0.72 to 1.12$)$ & & 1.35 (0.84 to 2.18$)$ & \\
\hline Widower/widow & 0.95 (0.87 to 1.04$)$ & & 0.84 (0.60 to 1.18$)$ & & 1.43 (0.80 to 2.55$)$ & \\
\hline Race/colour & & 0.584 & & 0.638 & & 0.796 \\
\hline White/yellow & 1.00 & & 1.00 & & 1.00 & \\
\hline Black/brown/indigenous & 1.01 (0.97 to 1.06$)$ & & 0.98 (0.88 to 1.08$)$ & & 0.96 (0.73 to 1.28$)$ & \\
\hline \multicolumn{7}{|l|}{ Socioeconomic block $\ddagger$} \\
\hline Education & & 0.457 & & $<0.001$ & & 0.967 \\
\hline $\begin{array}{l}\text { Higher education or } \\
\text { above }\end{array}$ & 1.00 & & 1.00 & & 1.00 & \\
\hline High school & $1.02(0.94$ to 1.11$)$ & & 0.82 (0.70 to 0.96$)$ & & 0.91 (0.51 to 1.62$)$ & \\
\hline Middle school & 1.03 (0.93 to 1.13$)$ & & 0.72 (0.60 to 0.87 ) & & 0.96 (0.51 to 1.79$)$ & \\
\hline $\begin{array}{l}\text { Elementary school or } \\
\text { less }\end{array}$ & 1.05 (0.96 to 1.15$)$ & & 0.62 (0.51 to 0.74$)$ & & 0.97 (0.52 to 1.77$)$ & \\
\hline Economic classification & & 0.031 & & $<0.001$ & & 0.677 \\
\hline$A-B$ & 1.00 & & 1.00 & & 1.00 & \\
\hline C & 0.94 (0.89 to 0.98$)$ & & 0.71 (0.64 to 0.78$)$ & & 0.88 (0.63 to 1.23$)$ & \\
\hline D-E & 0.94 (0.89 to 1.00$)$ & & 0.65 (0.57 to 0.75$)$ & & 0.98 (0.66 to 1.44$)$ & \\
\hline Occupation & & $<0.001$ & & 0.001 & & 0.001 \\
\hline Formal job & 1.00 & & 1.00 & & 1.00 & \\
\hline Informal job & 0.84 (0.80 to 0.89$)$ & & 0.82 (0.73 to 0.92$)$ & & $0.52(0.36$ to 0.77$)$ & \\
\hline Retired & 0.95 (0.88 to 1.02$)$ & & 0.63 (0.46 to 0.86$)$ & & 0.78 (0.47 to 1.27$)$ & \\
\hline Student/housewife & 0.89 (0.84 to 0.94$)$ & & 0.79 (0.67 to 0.89$)$ & & 0.83 (0.60 to 1.15$)$ & \\
\hline Unemployed & 0.97 (0.92 to 1.03$)$ & & 0.77 (0.67 to 0.89$)$ & & 0.63 (0.41 to 0.97$)$ & \\
\hline \multicolumn{7}{|l|}{ Health block§ } \\
\hline Private health insurance & & $<0.001$ & & $<0.001$ & & 0.304 \\
\hline No & 1.00 & & 1.00 & & 1.00 & \\
\hline Yes & 1.14 (1.10 to 1.19$)$ & & 1.25 (1.13 to 1.38$)$ & & 1.07 (0.78 to 1.47$)$ & \\
\hline Health status & & $<0.001$ & & $<0.001$ & & $<0.001$ \\
\hline Very good & 1.00 & & 1.00 & & 1.00 & \\
\hline Good & 1.36 (1.25 to 1.48$)$ & & 1.38 (1.19 to 1.60$)$ & & 0.97 (0.62 to 1.51$)$ & \\
\hline Fair & 1.46 (1.34 to 1.59$)$ & & 1.27 (1.08 to 1.49$)$ & & 1.44 (0.92 to 2.27$)$ & \\
\hline
\end{tabular}


Table 2 Continued

\begin{tabular}{|c|c|c|c|c|c|c|}
\hline & Physician & & Dentist & & Hospitalisation & \\
\hline Variable & PR $(95 \%$ Cl) & P value* & PR (95\% Cl) & P value* & PR $(95 \% \mathrm{Cl})$ & P value* \\
\hline Bad & 1.45 (1.31 to 1.61$)$ & & 1.44 (1.13 to 1.83$)$ & & $1.82(1.03$ to 3.21$)$ & \\
\hline Very bad & 1.30 (1.09 to 1.54$)$ & & 1.01 (0.60 to 1.70$)$ & & 3.46 (1.74 to 6.86$)$ & \\
\hline City & & 0.522 & & 0.168 & & 0.015 \\
\hline Capital & 1.00 & & 1.00 & & 1.00 & \\
\hline Countryside & 0.98 (0.93 to 1.03$)$ & & 0.92 (0.81 to 1.04$)$ & & 0.57 (0.37 to 0.90$)$ & \\
\hline Health reference & & 0.001 & & $<0.001$ & & $<0.001$ \\
\hline No & 1.00 & & 1.00 & & 1.00 & \\
\hline Yes & 1.06 (1.02 to 1.10$)$ & & 1.19 (1.09 to 1.29$)$ & & 1.75 (1.31 to 2.38$)$ & \\
\hline
\end{tabular}

Significant variables kept in each block of analysis:

${ }^{*}$ Adjusted Wald test.

Physician visit: †sex, age, marital status and race; łsex, age, marital status, education, income, occupation;§sex, age, marital status, income, occupation, private health insurance, health status, city and health reference.

Dentist visit:†sex, age, marital status and income; †sex, age, marital status, education, income, occupation;§sex, age, marital status, education, income, occupation, private health insurance, health status, city and health reference.

Hospitalisation:†sex, age, marital status and income; ¥sex, education, income, occupation;§sex, private health insurance, health status, city and health reference.

$58 \%$ reported lack of facilities or appointment unavailable and $14 \%$ reported lack of doctors. The majority of these people $(77 \%)$ sought service again, trying $1.4 \pm 1.2$ times in average.

\section{DISCUSSION}

Around 8 out of 10 interviewees went to a physician in the past year. Women, the elderly, widows/widowers, retirees, individuals who do not work, people with health insurance, and those who reported lower health were those who most used this service. About one-third of the interviewees accessed dental care in the period. Greater use occurred with younger age, higher incomes, higher levels of education, formal employment and health insurance. Out of 100 interviewees, seven were hospitalised in the previous year. Hospitalisations were associated with women, students and housewives, and people with very bad perception of their health status. Tertiary healthcare was the most sought level of care, and the majority of individuals had their last consultation with a general practitioner. Diseases were the main motivations for seeking healthcare in the past 15 days. Difficulty accessing health services was attributed to a lack of vacancy at healthcare facilities and a lack of available doctors.

Our study has some limitations. First, we obtained a $76 \%$ response rate. Low response rates are a frequent limitation in this type of population survey and may constitute a source of selection bias. Our efforts to improve representativeness included the random selection of one subject per household using predefined quotas for sex and age based on the official estimates. $^{11}$
The study presents the common limitations of cross-sectional designs. The outcomes were measured at a single point in time, making it impossible to establish causality. Other limitations are related to memory bias, since people tend to recall past activities to a greater or lesser degree depending on how important the activities were in their lives. ${ }^{19}$ The absence of an uniformity between the available surveys (recall periods, age range) makes comparability at both national and international levels difficult. The response rate was above $70 \%$, however, systematic differences in people who accepted and refused to participate is possible and weakens our results. To mitigate distortions in representativeness, inclusion of participants was based in predefined quotas of sex and age, based on official estimates.

The prevalence of physician visits in this study was similar to inquiries conducted in other Brazilian settings. ${ }^{20-23}$ Similarly to other studies, a higher use of physician visits was observed for the elderly, people with poorer perception of health status and health insurance. ${ }^{24}{ }^{25}$ The use of physician visits in the last 12 months ranged from $63 \%$ to $94 \%$ between Sweden and Spain. ${ }^{26}$ With a 90 -day recall period, other national studies have identified prevalence rates of $60 \%, 42 \%$ and $35 \% .{ }^{21} 2728$ In Latin America, the prevalence in the last 30 days was $41 \%$ among individuals who use public services and 39\% among private insurance holders in a study conducted in Peru. ${ }^{29}$

More than $80 \%$ of women attended a medical appointment in the last year in our study. In addition to factors related to preventative care. This result was similar to those from other Brazilian studies (82\%$86 \%)^{20} 30$ and around the world. A Norwegian survey 
Table 3 Issues related to use and access of health services in the previous 15 days

\begin{tabular}{lrc}
\hline Variables & N & $\%^{*}$ \\
\hline $\begin{array}{l}\text { When sick or in need of medical attention, you usually seek } \\
\text { for: } \\
\text { Primary services }\end{array}$ & 1208 & 30.2 \\
Secondary services & 598 & 14.9 \\
Tertiary services & 1886 & 47.2 \\
\hline Others & 309 & 7.7
\end{tabular}

What kind of doctor did you receive at your last visit?

$\begin{array}{lrr}\text { General practitioner } & 2995 & 77.1 \\ \text { Gynaecologist } & 402 & 10.3 \\ \text { Specialist } & 489 & 12.6\end{array}$

On the last 15 days did you seek for a service or professional for care related to your own health?

\begin{tabular}{lrc} 
Yes & 838 & 20.9 \\
No & 3183 & 79.1 \\
What was the main reason for which you seek care on the \\
$\begin{array}{l}\text { last 15 days? } \\
\text { Disease }\end{array}$ & 367 & 43.7 \\
Diagnostic examination & 117 & 14.1 \\
\hline Dental problem & 73 & 8.7 \\
Continued treatment & 68 & 8.1 \\
Other preventive care & 31 & 3.7 \\
Prenatal & 29 & 3.4 \\
Vaccination & 26 & 3.1 \\
Accident or injury & 26 & 3.1 \\
\hline Paediatric & 10 & 1.2 \\
Childbirth & 8 & 1.0 \\
Other & 83 & 9.9 \\
Did you receive care on the first & & \\
try? & & \\
Yes & 707 & 84.4 \\
\hline No & 131 & 15.6 \\
\hline
\end{tabular}

What was the reason for not receiving care on the last 2 weeks? (on the first attempt)

\begin{tabular}{|lrr|}
\hline Lack of vacancy or appointment & 76 & 57.9 \\
\hline Lack of doctors & 19 & 14.5 \\
\hline Lack of dentists & 3 & 2.3 \\
\hline $\begin{array}{l}\text { Lack of service of specialised } \\
\text { professionals }\end{array}$ & 6 & \\
\hline Long time waiting & 9 & 4.6 \\
\hline Service not working & 3 & 2.9 \\
\hline Others & 15 & 11.4 \\
\hline
\end{tabular}

In the last 2 weeks, how many times did you go back to seeking care?

\begin{tabular}{lll} 
Once & 648 & 77.3 \\
More than two & 190 & 22.7 \\
\hline & & Continued
\end{tabular}

\begin{tabular}{lrr}
\hline Table 3 Continued & N & $\%^{*}$ \\
\hline Variables & & \\
\hline $\begin{array}{l}\text { What was the main healthcare } \\
\text { received? }\end{array}$ & 642 & 76.5 \\
\hline $\begin{array}{l}\text { Doctor visit } \\
\text { Dentist visit }\end{array}$ & 72 & 8.6 \\
\hline $\begin{array}{l}\text { Laboratory, imaging or } \\
\text { complementary diagnostic tests }\end{array}$ & 35 & 4.3 \\
\hline $\begin{array}{l}\text { Vaccination } \\
\text { Injection, dressing or blood }\end{array}$ & 22 & 2.6 \\
pressure measurement & 11 & 1.3 \\
$\quad \begin{array}{l}\text { Consultation marking } \\
\text { Small ambulatory surgery }\end{array}$ & 10 & 1.2 \\
\hline Others & 8 & 1.0 \\
\hline
\end{tabular}

For what reason you did not seek a health service on the last 2 weeks?

\begin{tabular}{lrr} 
There was no need & 2823 & 89.3 \\
Lack of money & 91 & 2.9 \\
Long time waiting & 87 & 2.8 \\
Location of distant service & 54 & 1.7 \\
Incompatible hours & 48 & 1.5 \\
\hline Other & 60 & 1.9 \\
\hline
\end{tabular}

${ }^{*}$ Descriptive statistics using simple frequency.

conducted in 2008 revealed a $84 \%$ frequency of consultation in women compared with $74 \%$ in men, with similar results in hospitalisation rates (women $12 \%$ and men $11 \%){ }^{31}$

Regarding dental consultations, our findings were consistent with data from the Brazilian National Health Survey relevant to the North region, wherein $35 \%$ reported consultations in the last year. ${ }^{6}$ A Canadian population-based survey of 5600 individuals conducted in 2012 found that $75 \%$ of respondents had consulted a dentist in the previous year. Despite the high usage, the survey reports that only $34 \%$ needed dental treatment. ${ }^{32}$

A systematic review included 659043 individuals of Brazilian studies and detected a prevalence of $37 \%$ of dental visit in the last year, ${ }^{7}$ a similar rate to our study. Greater use was observed in individuals with higher income, higher education levels, formal job and health insurance, showing that lower use of dentist services is related to inequities in access. Negative outcomes in oral health are expected in the most vulnerable populations. In more socialised contexts, this inequality is also observed, with higher usage of dentist by richest and more educated people. ${ }^{33}$

We found a lower rate of hospital admissions when comparing to surveys conducted in the Brazilian Midwest and South regions, which varied from $9 \%$ to $15 \% .{ }^{23} 2734$ Higher prevalence in hospitalisation during the last year was positively associated to 
female sex, lower perception of health states, use of the same health service when needed. In previous studies, there was strong association with the elderly, in contrast to our findings. ${ }^{34}$ There are no previous reports of hospitalisation rates in the metropolitan region of Manaus for comparison. The 2013 Brazilian National Health Survey revealed a prevalence of $5.8 \%$ for hospitalisations in the North region. ${ }^{6}$ More than $70 \%$ of hospital admission in the Northern region occur in the Brazilian Health System, ${ }^{6}$ showing a high dependency on the public system in this area.

The low availability of hospital beds in the study may be contributing to the low prevalence of hospitalisation in Greater Manaus. In Amazonas, the density of hospital beds was 1.9:1000 inhabitants in 2009, compared with the Brazilian average (2.3:1000) and more developed regions of Brazil (Rio Grande do Sul, 5.3:1000). ${ }^{36}$ The supply of beds in Brazil is low compared with countries in the Organisation for Economic Cooperation and Development (4.8 beds per 1000 inhabitants) ${ }^{37}$ This finding could also be explained by the relative youth of the population, ${ }^{38}$ who require fewer hospitalisations than an older population. ${ }^{39}$

Despite the low prevalence of hospital admission, there is high demand for tertiary services in the occurrence of illness, overloading the healthcare services and causing higher expenses to the sector than if demand was organised through primary healthcare. ${ }^{40}$

A North American study reported that $51 \%$ of non-critically ill adults admitted to the emergency department indicated non-medical factors in the use of the service (lack of information, 23\%, inadequate access to specialised outpatient care, $14 \%$, need for diagnostic examination, $12 \%$, inadequate access to primary care, $10 \%) .{ }^{41}$

Among people who failed to use health service in the last fortnight the lack of vacancy in the health services accounted for almost $60 \%$ of the reason. Such proportion was superior to those found in a study carried out in 2012 in the Brazilian Southern Region. ${ }^{42}$ A Canadian national survey with 30222 individuals analysed barriers for healthcare access. ${ }^{43}$ They reported that $23 \%$ was related to waiting time and $16 \%$ was attributable to unavailable services. Other study performed in four African countries in 2010-2014 shows other issues perceived for lack of access. ${ }^{44}$ The interviewed claimed to poor transportation, unavailable services, inadequate drugs or supplies and the cost of the visit.

\section{CONCLUSION}

Physician visits are frequent among the residents of the region, but limitations exist in the use of dental care, with a higher usage rate in elevated economic and educational strata. Tertiary service is the most sought after first attendance, and hospitalisations are less frequent in comparison to other areas of Brazil. The findings point to the need for action within provider organisations to offer services that promote better equity and flow of treatment.
Contributors MTS, TFG, MEAA and MGP designed the study. MEAA and MTS performed the statistical analyses. MEAA drafted the manuscript. All authors interpreted the results, made critical revisions and provided intellectual content to the manuscript, approved the final version and agree to be accountable for all aspects of this work.

Funding This work was funded by National Council for Scientific and Technological Development (Conselho Nacional para o Desenvolvimento Científico e Tecnológico CNPq), [404990/2013-4 and 448093/2014-6, to MTS] and Foundation for Research Support of the State of Amazonas (Fundação de Amparo à Pesquisa do Estado do Amazonas - FAPEAM), [062.00253.2014, to MEAA].

Competing interests None declared.

Patient consent Obtained.

Ethics approval Ethics Committee of the Federal University of Amazonas approved the project through protocol no. 974.428 of March 2015.

Provenance and peer review Not commissioned; externally peer reviewed.

Data sharing statement Data are available and can be accessed by contacting MTS.

Open Access This is an Open Access article distributed in accordance with the Creative Commons Attribution Non Commercial (CC BY-NC 4.0) license, which permits others to distribute, remix, adapt, build upon this work non-commercially, and license their derivative works on different terms, provided the original work is properly cited and the use is non-commercial. See: http://creativecommons.org/ licenses/by-nc/4.0/

C) Article author(s) (or their employer(s) unless otherwise stated in the text of the article) 2017. All rights reserved. No commercial use is permitted unless otherwise expressly granted.

\section{REFERENCES}

1. Pereira MG. Epidemiologia: teoria e prática. 16th edn: Rio de Janeiro Editora Ganabara-Koogan, 1995.

2. Giovanella L. Determinantes e desigualdades sociais no acesso e na utilização de serviços de saúde. Polítícas e Sistema de Saúde no Brasil. 2nd edn. Rio de Janeiro, 2012.

3. Landmann-Szwarcwald C, Macinko J. A panorama of health inequalities in Brazil. Int J Equity Health 2016;15:174.

4. Viacava F, Dachs N, Travassos C. Os inquéritos domiciliares e o sistema nacional de informações em saúde. Cien Saude Colet 2006;11:863-9.

5. Malta DC, Leal MdoC, Costa MFL, et al. Inquéritos nacionais de saúde: experiência acumulada e proposta para o inquérito de saúde brasileiro. Rev Bras Epidemiol 2008;11:159-67.

6. Viacava F, Bellido JG, saúde C. Condições de saúde, acesso a serviços e fontes de pagamento, segundo inquéritos domiciliares: Revista Ciência \& Saúde Coletiva, 2016.

7. Araújo MEA, Silva MT, Andrade KRC, et al. Prevalence of health services utilization in Brazil: a systematic review and meta-analysis. Epidemiol Serv Saude 2017;26:587-604.

8. Silva MT, Galvao TF. Uso de serviços de saúde entre adultos residentes na região metropolitana de manaus: Inquérito de base populacional, 2015. Epidemiol Serv Saúde 2017;26.

9. Instituto Brasileiro de Geografia e Estatística (IBGE). Estimativas populacionais para os municípios brasileiros em 01.07.2013. 2013 http://www.ibge.gov.br/home/estatistica/populacao/estimativa2013/ default.shtm (accessed 10 Feb 2016).

10. Institute for Applied Economic Research. Atlas do desenvolvimento humano nas Regiões Metropolitana Brasileira. 2014 http://www. atlasbrasil.org.br/2013/data/rawData/publicacao_atlas_rm.pdf (accessed 5 Mar 2016).

11. Instituto Brasileiro de Geografia e Estatística (IBGE). Censo demográfico de 2010. http://www.censo2010.ibge.gov.br/sinopse/ index. php? $\mathrm{uf}=13 \&$ dados $=4$ (accessed 20 Jan 2016).

12. Instituto Brasileiro de Geografia e Estatística (IBGE). Estimativas populacionais para os municípios brasileiros em 01.07.2013. http:// www.ibge.gov.br/home/estatistica/populacao/estimativa2013/ default.shtm.

13. ABEP. Associação brasileira de empresas de pesquisa. Critério de classificação econômica brasil. 2015 http://www.abep.org/criteriobrasil (accessed 10 Aug 2017).

14. Kneipp SM, Yarandi HN. Complex sampling designs and statistical issues in secondary analysis. West $J$ Nurs Res 2002;24:552-66.

15. Victora CG, Huttly SR, Fuchs SC, et al. The role of conceptual frameworks in epidemiological analysis: a hierarchical approach. Int $J$ Epidemiol 1997;26:224-7. 
16. Espelt A, Marí-Dell'Olmo M, Penelo E, et al. Applied Prevalence Ratio estimation with different Regression models: An example from a cross-national study on substance use research. Adicciones 2016;29:105-12.

17. Barros AJ, Hirakata VN. Alternatives for logistic regression in crosssectional studies: an empirical comparison of models that directly estimate the prevalence ratio. BMC Med Res Methodol 2003;3:1.

18. Fotouhi AR. Modelling overdispersion in longitudinal count data in clinical trials with application to epileptic data. Contemp Clin Trials 2008;29:547-54.

19. Coughlin SS. Recall bias in epidemiologic studies. J Clin Epidemiol 1990;43:87-91.

20. Boing AF, Matos IB, Arruda MP, et al. [Prevalence of medical visits and associated factors: a population-based study in Southern Brazil] Rev Assoc Med Bras 2010;56:41-6.

21. Bastos GA, Santos IS, da Costa JS, et al. [Ambulatory care utilization in the past 15 years: comparison between two population-based studies]. Rev Bras Epidemiol 2011;14:620-32.

22. Mendoza-Sassi R, Béria JU. Prevalence of having a regular doctor, associated factors, and the effect on health services utilization: a population-based study in Southern Brazil. Cad Saude Publica 2003;19:1257-66.

23. Bastos GAN, Harzheim E, Sousa Alde. Prevalência e fatores associados à consulta médica entre adultos de uma comunidade de baixa renda do Sul do Brasil. Epidemiologia e Serviços de Saúde 2014:23:409-20.

24. Bastos GA, Duca GF, Hallal PC, et al. Utilization of medical services in the public health system in the Southern Brazil. Rev Saude Publica 2011:45:475-54.

25. Boccolini CS, de Souza Junior PR. Inequities in healthcare utilization: Results of the brazilian national health survey, 2013. Int J Equity Health 2016:15:150.

26. Stankunas $M$, Avery $M$, Lindert $J$, et al. Healthcare and aging: Do european union countries differ? Int J Health Care Qual Assur 2016;29:895-906.

27. Galvao TF, Silva MT, Gross R, et al. Medication use in adults living in Brasilia, Brazil: a cross-sectional, population-based study. Pharmacoepidemiol Drug Saf 2014;23:507-14.

28. Dilélio AS, Tomasi E, Thumé E, et al. [Patterns in the use of outpatient care in brazil by patients treated through the brazilian unified national health system, private health insurance, and out-of-pocket medical care]. Cad Saude Publica 2014;30:2594-606.

29. Ypanaqué-Luyo P, Martins M. [Utilization of outpatient health services in the Peruvian population]. Rev Peru Med Exp Salud Publica 2015;32:464-70.

30. Dias-da-Costa JS, Presser AD, Zanolla AF, et al. [Use of outpatient health services by women: a population-based study in southern Brazil]. Cad Saude Publica 2008;24:2843-51.
31. Vikum E, Bjørngaard JH, Westin S, et al. Socio-economic inequalities in norwegian health care utilization over 3 decades: The hunt study. Eur J Public Health 2013;23:1003-10.

32. Ramraj C, Azarpazhooh A, Dempster L, et al. Dental treatment needs in the canadian population: analysis of a nationwide cross-sectional survey. BMC Oral Health 2012;12:46.

33. Vikum E, Krokstad S, Holst D, et al. Socioeconomic inequalities in dental services utilisation in a Norwegian county: the third Nordtrondelag health survey. Scand J Public Health 2012;40:648-55.

34. Garbinato LR, Béria JU, Figueiredo ACL, et al. Prevalência de internação hospitalar e fatores associados: um estudo de base populacional em um centro urbano no Sul do Brasil. Cad Saude Publica 2007:23:217-24.

35. Costa JS, Reis MC, Silveira Filho CV, et al. Prevalence of hospitalization and associated factors in Pelotas, Southern Brazil. Rev Saude Publica 2010;44:923-33.

36. RIPSA Indicadores e dados básico para a Saúde. número de leitos hospitalares por habitante. http://tabnet.datasus.gov.br/cgi/tabcgi. exe?idb2012/e02.def (accessed 15 Dec 2016).

37. OECD 2015. Health at a Glance 2015: OECD indicators. $2015 \mathrm{http} / / /$ www.keepeek.com/Digital-Asset-Management/oecd/social-issuesmigration-health/health-at-a-glance-2015_health_glance-2015-en\# page4 (accessed 03 Feb 2017)

38. Vasconcelos AMN, Gomes MMF. Transição demográfica: a experiência brasileira. Epidemiologia e Serviços de Saúde 2012;21:539-48.

39. Palacios-Ceña D, Hernández-Barrera V, Jiménez-García R, et al. Has the prevalence of health care services use increased over the last decade (2001-2009) in elderly people? A Spanish population-based survey. Maturitas 2013;76:326-33.

40. Paim J, Travassos C, Almeida C, et al. The Brazilian health system: history, advances, and challenges. The Lancet 2011;377:1778-97.

41. Lewis Hunter AE, Spatz ES, Bernstein SL, et al. Factors influencing hospital admission of non-critically ill patients presenting to the emergency department: a Cross-sectional Study. J Gen Intern Med 2016;31:37-44.

42. Nunes BP, Thumé E, Tomasi E, et al. Socioeconomic inequalities in the access to and quality of health care services. Rev Saude Publica 2014;48:968-76.

43. Wilson K, Rosenberg MW. Accessibility and the Canadian health care system: squaring perceptions and realities. Health Policy 2004:67:137-48.

44. Eide $\mathrm{AH}$, Mannan $\mathrm{H}$, Khogali M, et al. Perceived barriers for accessing health services among individuals with disability in four african countries. PLoS One 2015;10:e0125915. 